6. Kokhanik I. N. (2006). Dynamics of meaning formation in a musical style. Scientific Herald National Music Academy of Ukraine named after P. I. Tchaikovsky. Vyp. 60. Kyiv [in Ukrainian].

7. Piaskovsky I. B. (1991). Updating romantic and post-romantic traditions in the harmonious thinking of B. Lyatoshinsky. Ukrainian music. Vyp. 26. Kyiv [in Ukrainian].

8. Rakunova I. M. (2008). The new composition technologies (using compositions of Alla Zahaykevych as examples). : authoref. dis. ... cand. must. : 17.00.03. Kyiv [in Ukrainian].

9. Syuta B. O. (2005). Intertextuality as a means of organizing the musical formes in the Ukrainian music in the postmodernism. Scientific Herald National Music Academy of Ukraine named after P. I. Tchaikovsky: Ukrainian and world music culture: modern look. Vyp. 36, Prince. 1. Kyiv [in Ukrainian].

10. Shesterenko I. V. "The most important thing is your own style" (an exclusive interview with Valery Antonyuk). Music: electronic vers. Journals. № 3. Kyiv. URL: http://music.cultua.media/2816-valerij-antonyuknajholovnishe-dlya-mene-stvoryty-vlasnyj-styl/ (due date: December 22, 2018) [in Ukrainian].

11. Ship S. V. (1979). About “technicalism” in avant-garde music. Music. № 3. Kyiv [in Ukrainian].

12. Shulgin D. (1998). Edison Denisov's Confession: based on interviews. Moskva : Composer. URL: http://dishulgin.narod.ru. (date of the beast: February 25, 2018) [in Russian].

Стаття надійшла до редакиії 01.02.2019 p.

УДК 78.092-027.543+792.78]:7-044.247(477:4)

\author{
Дружинець Маріанна Ігорівна, \\ викладач кафедри естрадного співу \\ Київської муніципальної академії естрадного \\ та циркового мистецтв, \\ здобувач Національної академії керівних кадрів \\ культури і мистецтв \\ ORCID 0000-0003-2843-8138 \\ marianna.druzhinec@gmail.com
}

\title{
ПІСЕННИЙ КОНКУРС ЄВРОБАЧЕННЯ ТА ВОКАЛЬНІ ТЕЛЕВІЗІЙНІ ТАЛАНТ- ШОУ ЯК ФАКТОР ЄВРОПЕЇЗАЦІЇ ТА ЄВРОІНТЕГРАЦІЇ УКРАЇНСЬКОЇ КУЛЬТУРИ
}

\begin{abstract}
Мета статті - розглянути основні тенденції і перспективи розвитку пісенного конкурсу Євробачення та вокальних талант-шоу «Х-Фактор», «Голос країни» в медіа-просторі України; розкрити їх специфіку та функціонування, визначити позитивні та негативні сторони, показати їх роль в європеїзації та євроінтеграції української культури. Методологія дослідження полягає в застосуванні компаративного, історико-логічного, аналітичного методів. Зазначений методологічний підхід дозволяє розкрити та піддати аналізу пісенний конкурс, вокальні талант-шоу, що транслювалися на українських каналах. Наукова новизна. Вперше у цій статті намагалися висвітлити специфіку та основні тенденції пісенного конкурсу Свробачення, телевізійних талант-шоу («Х-Фактор», «Голос країни»), розглянути їх як фактор європеїзації та євроінтеграції української культури. Проте недостатня розробленість в науці проблеми робить деякі положення дискусійними, розв'язання яких є важливим для сучасного культурного життя. Висновки. На українському екрані вже були представлені всі основні західні формати вокальних талант-шоу. До їх позитивних сторін можна віднести такі: втілення мрії в життя; спів «вживу»; професійна режисура та кращі представники вітчизняного шоу-бізнесу, а також зарубіжні фахівці; використання класичних творів світового та вітчизняного естрадного мистецтв, хітів 3 легендарних мюзиклів ХХ століття. Негативні сторони: відсутність довіри глядачів до чесності та об'єктивності організаторів при визначенні переможців. Шоу-проекти не є рівнозначними, відрізняються один від одного ступенем своєї креативності, багатством репертуарної палітри. Але спільними рисами вокального телешоу є те, що глядач знайомиться 3 реальними прикладами того, як завдяки поєднанню таланту, прагнення до самовдосконалення і напруженої праці збуваються мрії. Таким чином, поява в етері більшості популярних вітчизняних телеканалів вокальних талант-шоу, створених переважно на основі західних форматів, свідчить про високий ступінь європеїзації та євроінтеграції України у світову культуру масового зразка. Конкурс Свробачення дає можливість нашим артистам нести свою творчість в Свропу, у світ, тим самим інтегрувати українську культуру. Цей конкурс є стимулом для українських артистів, які, перш ніж виходити на світовий ринок у конкурсі Євробачення, - європеїзують свою творчість, роблять якісний європейський продук світового рівня, не втрачаючи при цьому кодовості української нації та культури.

Ключові слова: вокал, талант-шоу, європеїзація, євроінтеграція, пісенний конкурс Євробачення, «ХФактор», «Голос країни».
\end{abstract}

(C) Дружинець М. I., 2019 
Дружинец Марианна Игоревна, преподаватель кафедры эстрадного пения Киевской муниципальной академии эстрадного и ичркового искусств, соискатель Наџиональной академии руководящих кадров культурь и искусств

Песенный конкурс Евровидение и вокальные телевизионные талант-шоу как фактор европеизации и евроинтеграции украинской культуры

Цель статьи - рассмотреть основные тенденции и перспективы развития песенного конкурса Евровидение и вокальных талант-шоу «Х-Фактор», «Голос страны» в медиа-пространстве Украины; раскрыть их специфику и функционирование, определить положительные и отрицательные стороны, показать их роль в европеизации и евроинтеграции украинской культуры. Методология исследования заключается в применении сравнительного, историко-логического, аналитического методов. Указанный методологический подход позволяет раскрыть и подвергнуть анализу песенный конкурс, вокальные талант-шоу, которые транслировались на украинских каналах. Научная новизна. Впервые в этой статье пытались осветить специфику и основные тенденции песенного конкурса Евровидение, телевизионных талант-шоу («Х-Фактор», «Голос страны»), рассмотреть их как фактор европеизации и евроинтеграции украинской культуры. Однако недостаточная разработанность в науке проблемы делает некоторые положения дискуссионными, решение которых важно для современной культурной жизни. Выводы. На украинском экране уже были представлены все основные западные форматы вокальных талант-шоу. К их положительных сторон можно отнести следующие: воплощение мечты в жизнь; пение «вживую»; профессиональная режиссура и лучшие представители отечественного шоу-бизнеса, а также зарубежные специалисты; использование классических произведений мирового и отечественного эстрадного искусств, хитов из легендарных мюзиклов ХХ века. Отрицательные стороны: отсутствие доверия зрителей к честности и объективности организаторов при определении победителей. Шоу-проекты не являются равнозначными, отличаются друг от друга степенью своей креативности, богатством репертуарной палитры. Но общими чертами вокального телешоу является то, что зритель знакомится с реальными примерами того, как благодаря сочетанию таланта, стремления к самосовершенствованию и напряженного труда сбываются мечты. Таким образом, появление в эфире большинства популярных отечественных телеканалов вокальных талант-шоу, созданных преимущественно на основе западных форматов, свидетельствует о высокой степени европеизации и евроинтеграции Украины в мировую культуру массового образца. Конкурс Евровидение дает возможность нашим артистам нести свое творчество в Европу, в мир, тем самым интегрировать украинскую культуру. Этот конкурс является стимулом для украинских артистов, которые, прежде чем выходить на мировой рынок в конкурсе Евровидение, европеизируют свое творчество, делают качественный европейский продук мирового уровня, не теряя при этом кодовости украинской нации и культуры.

Ключевые слова: вокал, талант-шоу, европеизация, евроинтеграция, песенный конкурс Евровидение, «Х-Фактор», «Голос страны».

Druzhinets Marianna, lecturer of the pop music department of Kyiv Municipal Academy of Pop and Circus Arts, the candidate of the pop art department of National Academy of Management of Culture and Arts

Eurovision song competition and vocal television talent shows as a factor of Europeanization and European integration of Ukrainian culture

The purpose of the article is to consider the main tendencies and prospects of the development of the Eurovision Song Contest and the vocal talent show «X-Factor», «Voice of the Country» in the media space of Ukraine; to reveal their specifics and functioning, to identify positive and negative sides, to show their role in Europeanization and European integration of Ukrainian culture. The methodology of the research is to apply comparative, historical and logical, analytical methods. This methodological approach allows us to reveal and analyze the song contest, vocal talent shows broadcast on Ukrainian channels. Scientific novelty. To highlight the specifics and main tendencies of the Eurovision Song Contest, the TV talent show («X-Factor», «Voice of the Country»), to consider them as a factor of Europeanization and European integration of Ukrainian culture is tried in this article for the first time. However, the lack of development of the problem in science makes some provisions of discussion, the solution of which is important for modern cultural life. Conclusions. All major western formats of vocal talent shows have already been presented on the Ukrainian TV. To their positive aspects following consequences can be attributed: the realization of a dream in life; singing at «live» format; professional directions and the best representatives of national show business, as well as foreign specialists; using classical works of world and national pop art, hits from the legendary musicals of the twentieth century. Negative sides: lack of spectators' trust to the honesty and objectivity of the organizers in defining the winners. Show projects are not equivalent, they differ from each other by the degree of their creativity, the richness of the variety of repertoire. But the common features of the vocal TV shows are that the viewer is introduced to real examples of how dreams come true through the combination of talent, the desire for self-perfection and hard work. Thus, the appearance in the ether of most popular national TV channels of vocal talent shows, created mainly on the basis of western formats, reveals the high degree of Europeanization and European integration of Ukraine in the world culture of the mass prototype. The Eurovision contest enables our artists to show their creativity in Europe and the world, thus integrating Ukrainian culture. This competition is an incentive for Ukrainian artists who «europeanize» their works before entering the world market in the Eurovision contest and make quality European products of world-class not losing the features of the Ukrainian nation and culture. 
Key words: vocal, talent show, Europeanization, European integration, Eurovision Song Contest, X-Factor, «Voice of the Country».

Актуальність теми дослідження. Яскравими явищами в культурному просторі України $\epsilon$ пісенний конкурс Євробачення та розважальні талант-шоу «Х-Фактор», «Голос країни» - цикл передач, в якому відбувається змагання учасників-конкурсантів, що демонструють свої здібності, уміння й обдарування. Міжнародний пісенний популярний конкурс Свробачення та велика кількість шоу на екрані, прискіплива увага до них з боку журналістики, дані соціологічних опитувань про високий рейтинг подібних передач обумовлюють актуальність дослідження цього питання. Стан вивчення вивчення телешоу ще не можна назвати задовільним. Попри значну кількість наукових робіт, присвячених зазначеним проблемам, не вистачає комплексних досліджень, в яких би простежувалися культурно-історичні прогресії талант-шоу, поглиблений культурологічний аналіз міжнародного пісенного конкурсу та їх ролі у європеїзації творчості артистів, учасників та євроінтеграції культури України, хоча варто звернути увагу на низку цікавих досліджень соціологічного, психологічного, культурологічного, музикознавчого напрямів, у яких зроблено важливі узагальнення.

Аналіз останніх досліджень та публікацій. У процесі вивчення телешоу, конкурсів-шоу не можна оминути загальні дослідження шоу як феномена культури (I. Коротаєва, В. Стаметов), шоутехнологій та загальної шоуїзації суспільства (К. Акопян, Н.Дубовик, М. Макуіценко. А. Скрипка). Концепт телевізійного шоу вже розробляється сучасними вченими, зокрема є праці про особливості історичного телешоу (А. Урушадзе, Т. Хлиніна) та реаліті-шоу (С. Гуцал, А. Оборська, А. Савенко, С.Уразова, Т. Шоріна).

Дослідники обирають різні критерії для визначення поняття «шоу»: характерні ознаки будьякого видовища, комунікативну складову, сокультурну специфіку, онтологічні виміри. Такі підходи свідчить не лише про масштабність та багатофункціональність означеного феномена, а й про його глибоке проникнення в усі сфери життя суспільства. Це явище вчені називають шоуїзацією. Так, Н.Дубовик у праці «Шоутизація сучасної культури», доходить висновку, шоу виходить за рамки телебачення та індустрії розваг, стаючи сучасною карнавалізованою формою культури, що дозволяє автору говорити про явище «шоутизації» [4, 224]. А. Скрипка у розвідці «Шоу-технології як форма соиіальної комунікації» наголошує, що шоу стає універсальною комунікативною практикою сучасного суспільства, елементи якої проникають в сфери суспільного життя $[8,8]$. Ю. Романенко подає своє тлумачення терміна «шоуїзація» у «Проективному філософському словнику», дослівний переклад - «показуха». На думку автора, шоуїзація - це устан сучасної цивілізації, обумовлена тотальним розповсюдженням засобів масової інформації і комуніції, яка виражається у маніпуляції зором натовпу, постійному прагненні виставити будь-які факти, явища напоказ, задоволенні гіпертрофованої психологічної потреби у видовищах [7, 7]. К. Акопян під терміном «шоуїзація» у праці «Шлягеризачія, шоуїзація $і$ ексгібіџіонізащія в сучасній культурі» має на увазі відносно самостійний процес розповсюдження шоу як специфічного соціокультурного феномена $[1,5]$.

Мета дослідження. Обгрунтувати основні тенденції, перспективи розвитку пісенного конкурсу-шоу та вокальних талант-шоу в медіа-просторі України та висвітлити їх роль в європеїзації та інтеграції української культури. Об’єктом дослідження є пісенний конкурс Євробачення та вокальні талант-шоу «Х-Фактор», «Голос країни». Предметом дослідження $\epsilon$ специфіка, функціонування, значення пісенного конкурсу Євробачення, вокальних талант-шоу «Х-Фактор», «Голос країни» як феноменів європеїзації та євроінтеграції української культури.

Виклад основного матеріалу. Поява «реальних шоу» (від англ. «Reality show») на телевізійних екранах є досить новим феноменом масової культури. Євробачення - популярний конкурс-шоу естрадної пісні серед країн-членів Свропейського мовного союзу (EBU). Талант-шоу на українському телебаченні представлене проектами, що $є$ аналогами популярних світових шоу: «Україна має талант», «Танцюють всі», «Супер зірка», «Фабрика зірок» «Х-фактор», «Голос країни» та ін., на двох останніх зупинимося конкретніше.

Євробачення - популярний конкурс естрадної пісні серед країн-членів Європейського мовного союзу (EBU). Конкурс проходить щорічно, починаючи з 1956 року, і є одним з найбільш популярних неспортивних заходів у світі. Україна стала активним учасником конкурсу з 2003 р. Менеджмент конкурсу з української сторони здійснює Національна телекомпанія України, загальну координацію цього міжнародного конкурсу здійснює Європейська Мовна Спілка. До 2004 року формат проведення шоу передбачав лише фінал, тобто проводився 1 день. Формат проведення Євробачення у 2 півфінали та фіналу існує з 2008 року. 
Україна є єдиною європейською країною на Євробаченні, яка завжди успішно проходила передфінальні відбори і завжди виступала у фіналі у роки своєї участі в конкурсі. Україна дебютувала на Пісенному конкурсі Євробачення 2003 року. Її представив співак Олександр Пономарьов із піснею «Наsta la Vista», де посів 14 сходинку. У 2004 році співачка Руслана 3 піснею «Wild Dances» здобуває перемогу й право на проведення ювілейного 50-го Пісенного конкурсу Євробачення в Україні. Європу підкорив номер української конкурсантки: справжнє шоу склалося 3 шаленого ритму, в основі якого відчувався фольклорний наспів запальної пісні виконавиці, іiі «диких танців» разом із хореографічним колективом «Життя», та виразні сценічні костюми. На Пісенному конкурсі Євробачення 2005 року Україну представив гурт «Гринджоли» 3 піснею «Разом нас багато», де посів 19 сходинку. У 2006 році Тіна Кароль 3 піснею «Show Me Your Love» посідає 7 місце. Визначним і виразним виступом України в Європі вважають номер Вєрки Сєрдючки (Андрія Данилка) у 2007 році. Саме цей виступ приніс Україні срібло. У 2008 році Україну на конкурсі представляла Ані Лорак 3 піснею «Shady Lady», співачка принесла нашій країні теж 2 місце; у 2009 році - Світлана Лобода 3 піснею «Ве my Valentine», артистка посіла 12 місце. У 2010 році нашій країні 10 місце привезла Alyosha 3 композицією «Sweet People», у 2011 році - 4 місце здобула Міка Ньютон з піснею «Angel». У 2012 році представляла нашу державу Гайтана і зайняла 15 місце. Злата Огневич 3 піснею «Gravity» у 2013 році знову повернула Україну на п'єдестал пошани. Номер, який представила українка, був видовищним: Ігор Вовковинський виніс Злату на руках і поставив на платформу-камінь, де вона перебувала під час всього виступу. За казкову пісню Україні віддали 214 балів - і це принесло у нашу скарбничку «бронзу». Марія Яремчук 3 піснею «Tick-Tock» на Євробачення у 2014 році в Копенгагені влаштувала справжнє шоу і отримала 6 місце. У 2015 році Україна вперше за всю історію конкурсу, у зв'язку зі складною ситуацією в країні, не брала участь у конкурсі. У 2016 році Україну представляла співачка Джамала 3 піснею «1944», яка здобула перемогу, набравши 534 бали. Це друга перемога України на пісенному конкурсі Євробачення. У 2017 році на конкурсі Євробачення-2017 Україну представив гурт «O.Torvald» 3 піснею «Тіте», яка зайняла 24 місце (це найгірший результат в історії участі України). На Свробаченні 2018 Україну представив співак Melovin, де отримав 17 місце [9]. У 2019 році перемогу на національному відборі отримала Maruv, та через політичні конфлікти, які виникли під час фінального ефіру та в подальшому, Україна не брала участь в конкурсі.

Євробачення - це конкурс, який дає можливість нашим артистам нести свою творчість в Європу, у світ, тим самим інтегрувати (інтеграція -асиміляція різнорідних елементів культури в єдину культуру [5]) українську культуру. Цей конкурс $\epsilon$ певним стимулом для український артистів, які перш ніж виходити на світовий ринок у конкурсі Євробачення, - європеїзують (європеїзація внутрішні зміни відповідно до західноєвропейських стандартів [5]) свою творчість.

У жовтні 2010 - січні 2011 рр. на телеканалі «СТБ» демонструвався перший український сезон вокального талант-шоу «Х-Фактор» (формат «X-Factor»). Х-Фактор ( українська версія британського проекту The X Factor - музичного талант-шоу, основною метою якого $\epsilon$ пошук і розвиток пісенного таланту конкурсантів. Всі конкурсанти обираються шляхом публічних прослуховувань, Міжнародну The X Factor серію започаткував британський проект, створений 2004 року відомим англійським продюсером Саймоном Ковеллом та компанією FremantleMedia. Адаптовані версії шоу були показані більш ніж у 20-ти країнах світу. На цей час проект «Ікс-Фактор» $\epsilon$ одним 3 найпопулярніших співочих талант-шоу у світі, а його переможці неодмінно стали яскравими фігурами у шоу-бізнесі у своїх країнах. Відбір учасників поділяється на п'ять етапів: Етап 1: Попередній кастинг, або Кастинг продюсерів; Етап 2: Телевізійний кастинг (судді обирають 100 найкращих виконавців); Етап 3: Тренувальний табір (судді відбирають 24 виконавців - по 6 виконавців у кожній категорії); Етап 4: Візит до суддів (суддя 36 обирає 3 найкращих, які боротимуться за перемогу у прямих ефірах); Етап 5: Прямі ефіри [11].

Рекламна кампанія «Х-Фактора» була особливо масштабною і пафосною, значним розмахом відрізнялася як процедура відбору конкурсантів, так і їхня боротьба за першість у фінальній частині. До участі в проекті були залучені деякі зірки світового рівня - переможець музичного конкурсу «Свробачення-2009» Олександр Рибак, французька співачка Патрісія Каас, італійський тенор Олександро Сафіна [10]. Переможці - 1 сезон: 1 місце (переможець) - Олексій Кузнєцов (Йолка); 2 місце (суперфіналіст) - Марія Рак (Ігор Кондратюк); 3 місце (фіналіст) - Олександр Кривошапко (Йолка); 2 сезон: 1 місце - Віктор Романченко (Серьога); 2 місце - Олег Кензов (Ігор Кондратюк); 3 місце - Владислав Курасов (Ггор Кондратюк); 3 сезон: 1 місце - Аіда Ніколайчук (Ігор Кондратюк); 2 місце - Свген Літвінкович (Ігор Кондратюк); 3 місце - Олексій Смирнов (Серьога); 4 сезон: 1 місце Олександр Порядинський (Ірина Дубцова); 2 місце - Колектив «Тріода» (Ігор Кондратюк); 3 місце - 
Сергій Гладир (Сергій Сосєдов); 5 сезон: 1 місце - Дмитро Бабак (Ніно Катамадзе); 2 місце - Тріо «Екстрім» (Станіслав Панькин, Ельдар Кабіров, Сергій Юрченко) (Сергій Сосєдов); 3 місце - Кирило Каплуновський (Ніно Катамадзе); 6 сезон:1 місце - Костянтин Бочаров (Ігор Кондратюк); 2 місце Богдан Совик (Сергій Сосєдов); 3 місце - Аліна Паш (Ніно Катамадзе); 7 сезон: 1 місце - Севак Ханагян (Антон Савлепов); 2 місце - «DETACH» (Олексій Веренчік, Денис Фандера, Максим Стадник, Руслан Войтович, Свген Астаф'єв), (Юлія Саніна); 3 місце - Mountain Breeze (Олександр Біляк, Ілля Біляк, Мирослав Щербак), (Андрій Данилко); 8 сезон: 1 місце - Михайло Панчишин (Дмитро Шуров); 2 місце - Yurcash (Андрій Данилко); 3 місце - Дар'я Ступак (NK); 9 сезон: 1 місце - «ZBSband» (NK); 2 місце - Дмитро Волканов (Андрій Данилко); 3 місце - Марк Савін (Дмитро Шуров) [11].

Багато молодих артистів вийшла 3 «Х-Фактору». Після перемоги на «Х-факторі» Олексій Кузнєцов вирушив до Австрії вдосконалювати свою майстерність. У 2013 році йому довірили співати Гімн України на відкритому тренуванні Нашої збірної на Євро. Взимку цього ж року Олексій Кузнєцов відлітає до США, у 2013 році його запрошено на закритий вечір класичної музики у Цюриху. У 2015 році він дає свій перший концерт у Гуанчжоу, Китай. У березня 2015 року в Палаці «Україна» в Києві відбувається прем'єра концерту пісень 3 мюзиклу Notre Dame de Paris, Олексій виконує партію Клода Фролло, підчас концерту у його виконанні звучать наступні арії: Tu vas me détruire, Être prêtre et aimer une femme - сольно, а також Belle, Fatalité, Florence, Où est-elle?, Visite de Frollo à Esmeralda, Un matin tu dansais, Libérés та L'attaque de Notre-Dame - спільно 3 іншими солістами. Віктор Романченко після шоу заспівав разом із легендарними Queen та Адамом Ламбертом. А в лютому 2018 року він випустила кліп на пісню «Болю не буде». Після тріумфу в «Хфакторі» Аїда Ніколайчук дає концерти, знімає кліпи и записує нові хіти. У 2013 році вона уклала контракт зі світовою компанією звукозапису Sony Music і презентувала свій перший сингл «На твоей планете». Потім презентувала свій перший кліп на пісню «На твоей планете», опісля - другий кліп «Не обещай». У 2013 році Аіда Ніколайчук випустила свій перший альбом «Ми під одним небом», у 2014 році вийшов сингл «Eternity», нові пісні «Музика», «Два неба». У 2016 році брала участь у півфіналі національного відбору Пісенного конкурсу «Євробачення 2016». Після перемоги на шоу Дмитро Бабак зняв кліп на пісню «Одна», встиг спробувати свої сили композитора і написав пісні для кількох українських артистів. Олександр Порядінській активно гастролює, об'їздив пів країни i випустив кліп на пісню «Поцілунок». MELOVIN активно займається творчістю, представляв Україну на Євробаченні-2018. Зараз MELOVIN гастролює Україною, розвивається як музикант. Варто відмітити таких учасниць проекту «X-фактор», як Мішель Андраде та Аліну Паш. Перша саме на цьому телевізійному конкурсі, хоч і не досягнула вагомих результатів безпосередньо на шоу, була помічена продюсером Потапом. Зараз співпрацює з продюсерським центром Mozgi Entertainment. Друга, Аліна Паш - фіналістка 6-го сезону проекту, презентувала дебютний сингл «Bitanga» (укр. «Бітанга») та відеокліп до нього. Вокалістка поп-артистів перетворюється на самостійну зірку. Про неї пишуть всі - від музичних блогів до великих видань; журналістів і слухачів переповнює ейфорією від того, що український фольк нарешті зустрівся з хіп-хопом та R`n`B [3].

«Голос країни» - телевізійне талант-шоу, виходить на телеканалі «1+1». Головна відмінність проекту в тому, що участь у шоу забезпечують насамперед вокальні здібності та талант; зовнішність і вік учасників мають вторинне значення. Шоу $є$ українською адаптацією формату The Voice, створеного медіа-магнатом Джоном де Молом у Нідерландах. Перший сезон відповідного проекту «Голос Голландії» (The Voice of Holland) добіг кінця на телеканалі RTL4 і мав шалений успіх в країні. Наступною країною, де було втілено проект, стали США. Україна стала третьою країною, де втілено цей формат, хоча права придбали понад 20 країн. Перший сезон шоу розпочався 22 травня 2011.

Окрім співаків-учасників, головними дійовими особами шоу є чотири тренери - відомі вокальні виконавці. Кожен тренер формує свою команду співаків, з якими співпрацюватиме на подальших етапах проекту. Під час проекту тренери не змінюють учасника, не обмежують його «форматом». Їх головна мета, за допомогою професійної команди підкреслити талант співака та вивести його на «музичну Говерлу» країни. В шоу мають місце професійні поради та підтримка учасників. Музичний продюсер шоу К. Меладзе. У третьому сезоні «Голосу країни» музичним продюсером став Ю. Шепета. Сам К. Меладзе продовжив роботу з проектом як консультант [2].

Головний приз «Голосу країни»- контракт із рекординговою компанією. Виступи відбуваються наживо в супроводі живого оркестру. В рамках «Голосу країни» також виходить спеціальне онлайнове шоу «3G-репортер»про закулісне життя проекту. Кастинг проекту відбувається у два етапи. Перший - доефірний, коли «голос країни» шукають всією Україною. 
Відбором керує музичний продюсер шоу. Так, участь у першому етапі кастингу першого сезону шоу взяли 5000 осіб, 3 яких до наступного етапу відібрали 150 учасників. Другий етап - «сліпі прослуховування» (або «Вибір наосліп»), де чотири тренери роблять свій вибір, орієнтуючись виключно на голос учасника. Під час виступу учасників тренери сидять спиною до сцени. Якщо до учасника під час виступу повернулося кілька тренерів, учасник сам обирає, в команду якого 3 можливих тренерів іти. Із 150 учасників другого етапу кастингу до наступного етапу змагань проходять лише 56 співаків (по 14 учасників в команді кожного тренера). Власне змагання в шоу також відбувається в два етапи. На першому «командному»етапі кожен тренер готує та відправляє на «ринг» двох вокалістів своєї команди для «музичного двобою» - спільного виконання однієї пісні (дует), після якого тренер вирішує, хто зі співаків залишається у команді, а хто вибуває. У результаті цього етапу, у кожній команді залишиться по шість вокалістів, які вже сольно змагаються за головний приз у прямих ефірах шоу. Під час кожного прямого ефіру інтерактивне голосування глядачів визначає лідерів, які проходять до наступного етеру. Серед інших, не «врятованих», конкурсантів тренери обирають також тих, хто на їхню думку може проявити себе найкраще у наступних етерах. Решта учасників або повторюють свої виступи на пустій сцені, і тренер має обрати хто залишає проект, або вибувають одразу. Такий формат ефірів повторюється до півфіналу, у якому глядацьке голосуванням разом з тренерськими преференціями спільно визначає переможців у кожній команді. У фіналі глядачі спершу визначають двох найкращих співаків за загальним голосуванням, а насамкінець - відбувається остаточне голосування глядачів для вибору кращого серед двох лідерів. Саме той і отримує головний приз конкурсу. Переможці: 1 сезон Іван Ганзера (переможеиь), Антоніна Матвієнко (2 місие), Владислав Ситник (3 місце); 2 сезон - Павло Табаков, Ангеліна Моняк, Назар Савко; 3 сезон - Ганна Ходорівська, Отар Немсадзе, Тарас Мельник; 4 сезон - Ігор Грохоцький, Марлен Карімов, Михайло Мирка; 5 сезон - Антон Копитін, Тетяна Решетняк, Андрій Лучанко; 6 сезон - Віталіна Мусієнко, Інна Іщенко, Владислав Каращук; 7 сезон - Олександр Клименко, Інгрет Костенко, Віра Кекелія; 8 сезон - Олена Луценко, Андрій Рибарчук, Анна Трінчер; 9 сезон - Оксана Муха, Карина Арсєнтьєва, Андрій Хайат [9].

Ціла плеяда молодих артистів вийшла 3 «Голосу країни». Переможець першого сезону Іван Ганзера підписав контракт 3 Universal Music в жовтні 2011 року. В грудні 2012 року Ганзера презентував дебютний альбом «Я не могу тебя терять». Переможець другого сезону Павло Табаков підписав контракт з Universal Music Group у грудні 2012 року, переможець третього сезону унікальний контракт з телеканалом $1+1$ для підтримки і розвитку кар'єри та запису дисків у відомій студії звукозапису «Комп Мьюзік» (2). Солістка молодого українського гурту KAZKA - учасниця четвертого сезону «Голосу країни» Олександра Зарицька. На сьогодні пісні KAZKA популярні, а гурт став відкриттям року 2017 за версією музичного видання Karabas Live. Усе частіше український слухач може почути і співака LAUD, тобто Влада Каращука. Саме на «Голосі країни» продюсер співачки Джамали відкрив для себе унікальний чоловічий вокал Влада і розпочав співпрацю 3 перспективним виконавцем премії YUNA та визнаним Дебютом року 2017 за версією музичного видання Karabas Live. Підопічна Потапа на «Голосі країни»-7 Інгрет Костенко не перемогла у шоу, але розпочала співпрацю з продюсерським центром MOZGI Entertainment. А Костянтин Дмитрієв під продюсерським крилом Івана Дорна став співаком CONSTANTINE. Тепер він пише пісні, випускає власні кліпи і спробував свої сили у нацвідборі на Євробачення з україномовною піснею «Місто». У другому сезоні «Голосу країни» українці дізналася і про доньку легендарного співака Назарія Яремчука - Марію. Після талант-шоу дівчина поїхала представляти Україну на Євробаченні у Копенгагені, де посіла 6-те місце, зараз вона випускає пісні, знімає кліпи та епатує новими образами. Тетяна Решетняк, нині відома як TAYANNA працює з продюсером Аланом Бадоєвим, 2017 року вона отримала нагороду від M1 Music Awards як Прорив року, а 2018-го була номінована на премію YUNA як Найкраща виконавиця. Співачка випустила два альбоми - «Портрети» та «Тримай мене». Христина Соловій не дійшла до фіналу, але продюсером іiі став Святослав Вакарчука, а пї чуттєві лемківські пісні стають хітами. Після участі у вокальному проекті Христина почала створювати авторські композиції. Перший кліп на пісню «Тримай» вийшов 2015 року та отримав нагороду музичної премії YUNA. Христина Соловій випустила альбом «Жива вода», декілька кліпів; вона активно концертує. Учасниця «Голосу країни»-7 Юлія Запорожець після участі у шоу продовжила творчий шлях і тепер виступає як JULINOZA. Леонардо Ободоеке - студент Тернопільського медичного університету (родом із Негерії) на «Голосі країни» потрапив до команди Святослава Вакарчука і відомий музикант продовжив співпрацю з ним після проекту. Перший сингл Лео «Листи» полюбився українським слухачам. Потім він першим в Україні презентував пісню, що прозвучала на 
піджин - суміші спрощеної англійської та однієї із 300 мов і діалектів Нігерії. Опісля співак презентував кліп «Вільна» [13].

Отже, на українському екрані вже були представлені всі основні західні формати вокальних талант-шоу. Обговорення виступів членами журі додає в них деякі елементи «ток-шоу», а закулісна підготовка до виконання кожного номера має схожість зі справжнім професійним шоу.

Однак питання про рівні цих проектів викликає чимало дискусій, де називаються як позитивні, так і негативні їх сторони. До позитивних сторін вокальних талант-шоу можна віднести такі: втілення мрії в життя; спів «вживу»; професійна режисура та кращі представники вітчизняного шоу-бізнесу, а також зарубіжні фахівці; використання класичних творів світового та вітчизняного естрадного мистецтв, хітів 3 легендарних мюзиклів XX століття. Однак $є$ й негативні сторони - серед глядачів і навіть частини експертів відсутня довіра до чесності та об'єктивності організаторів при визначенні переможців [12, 54]; учасники і навіть переможці вокальних талант-шоу після їх завершення зазвичай не можуть закріпитися у вітчизняному шоу-бізнесі, лише одиниці 3 них продовжують професійну кар'єру в даній сфері [6, 22].

Проаналізовані вище проекти не є рівнозначними, відрізняються один від одного ступенем своєї креативності, багатством репертуарної палітри. Але спільними рисами вокального телешоу є те, що глядач знайомиться з реальними прикладами того, як завдяки поєднанню таланту, прагнення до самовдосконалення і напруженої праці збуваються мрії. Конкретна людина може за короткий період часу пройти шлях від нереалізованих можливостей - до успіху.

Таким чином, поява в ефірі більшості популярних вітчизняних телеканалів вокальних талантшоу «Х-Фактор», «Голос країни», створених на основі західних форматів, та пісенного конкурсу Євробачення, свідчить про високий ступінь інтеграції України у світову культуру масового зразка. Отримавши високі стартові рейтинги, такі проекти, безумовно, широко представлені в українському телевізійному просторі.

\section{Jimepamypa}

1. Акопян К. Шлягеризация, шоуизация и эксгибиционизация в современной культуре. Горизонты культуры: от массовой до элитарной. Санкт-Петербург, 2008. С. 15-21.

2. Голос країни URL: https://uk.wikipedia.org/wiki. (дата звернення: травень 2018).

3. Доля фіналістів «X-Фактора». URL: https://xfactor.stb.ua/ru/2018/08/07/h-faktor-kak-slozhilas-sudbapobeditelej-vseh-sezonov-proekta-v-ukraine/ (дата зверення: травень 2018).

4. Дубовик Наталия Шоутизация современной культуры. V МICT: Мистецтво, історія, сучасність, теорія, 2010. № 7. С. 224-233.

5. Європеїзація. Євроінтеграція. URL: https://uk. wikipedia.org/wiki. (дата зверення: травень 2018).

6. Невольнева И. Поймать звезду: талант-шоу не гарантируют звездных доходов. Фокус, 2010. № 24. C. 21-22.

7. Романенко Юрий. Шоуизация. Проективный философский словарь: Новые термины и понятия URL : http://ontoimago.spb.nl/article_139.html. (дата зверення: травень 2018).

8. Скрипка Анна. Шоу-технології як форма соціальної комунікації : автореф. дис. на здобуття паук, ступеня канд. соціологічних наук : спец. 22.00.04. Харків, 2010.

9. Україна на пісенному конкурсі Євробачення. URL: https://uk.wikipedia.org/wiki. (дата зверення: травень 2018).

10. Фан-сайт шоу «X-Фактор» в Украине. URL : http://xfactor.kiev.ua. (дата зверення: травень 2018).

11. X-Фактор. URL: https://uk.wikipedia.org/wiki/X. (дата зверення: травень 2018).

12. Хабаров А. Скандал вокруг «Х-Фактора»: фальсифікаціям - «ні!». 2010. № 47.

13. Як склалася доля найяскравіших учасників Голосу країни URL: https://1plus1.ua/goloskrainy/novyny/ak-sklalasa-dola-najjaskravishih-ucasnikiv-golosu-kraini (дата зверення: травень 2018).

\section{References}

1. Akopjan, K. (2008). Hit-anization, show-anization and exhibitionism in contemporary culture.Ghoryzont kuljturb: ot massovoj do эlytarnoj. Sankt-Peterburgh. P. 15-21 [in Russian].

2. Voice of the country. Retrieved from: https://uk.wikipedia.org/wiki. [in Ukrainian].

3. The fate of the X-Factor finalists. Retrieved from: https://xfactor.stb.ua/ru/2018/08/07/h-faktor-kakslozhilas-sudba-pobeditelej-vseh-sezonov-proekta-v-ukraine/ [in Ukrainian].

4. Dubovyk, Natalyja. (2010). Show-anization of modern culture. V MIST: Mystectvo, istorija, suchasnistj, teorija. № 7. S. 224-233 [in Ukrainian].

5. Europeanization. European integration. Retrieved from: https://uk.wikipedia.org/wiki. [in Ukrainian].

6. Nevoljneva, Y. (2010). To catch the star: talent shows do not guarantee stellar income. Fokus. № 24. S. 2122 [in Russian]. 
7. Romanenko Juryj. Show-anization Retrieved from Retrieved from: http://ontoimago.spb.nl/article_139.html. [in Ukrainian].

8. Skrypka, Anna. (2010). Show-technology as a form of social communication: avtoref. dys. na zdobuttja pauk, stupenja kand. sociologhichnykh nauk : spec. 22.00.04. Kharkiv [in Ukrainian].

9. Ukraine at the Eurovision Song Contest. Retrieved: https://uk.wikipedia.org/wiki. [in Ukrainian].

10. Fan-site of the show "X-Factor" in Ukraine. Retrieved from: http://xfactor.kiev.ua. [in Ukrainian].

11. X-factor. Rezhym dostupa: https://uk.wikipedia.org/wiki/X. [in Ukrainian].

12. Khabarov, A. (2010). A scandal around the "X-Factor":"no!"to falsifications. 2010. № 47 [in Ukrainian].

13. How is the life of the brightest participants in the Voice of the country. Retrieved from: https://1plus1.ua/golos-krainy/novyny/ak-sklalasa-dola-najjaskravishih-ucasnikiv-golosu-kraini [in Ukrainian].

Стаття надійшла до редакиії 11.02.2019 p.

УДК 785.6:787.61

Тущенко Михайло Михайлович, старший викладач інституту мистецтв Київського університету імені Бориса Грінченка 0000-0002-4315-3651

tuschenko_m@ukr.net

\title{
М. СТЕЦЮН «ІСПАНСЬКИЙ КОНЦЕРТ» ДЛЯ ГІТАРИ З ОРКЕСТРОМ: ДО ПИТАННЯ СТВОРЕННЯ НАЦІОНАЛЬНОГО РЕПЕРТУАРУ В ГАЛУЗІ ГІТАРНОГО МИСТЕЦТВА
}

\begin{abstract}
Мета роботи - детальний аналіз «Іспанського концерту» для гітари із симфонічним оркестром М.Стецюна, розкриття його інтонаційної й композиційної єдності, особливостей творчого методу композитора. Особливу увагу дослідник приділяє стилістиці твору задля вияву поєднання рис двох національних шкіл української та іспанської (фламенко). Методом дослідження було обрано стилістичний, композиційний та інтонаційний аналіз твору. Актуальність роботи полягає в її відповідності сучасним потребам національного мистецтва та освіти, а саме в появі досліджень новітнього гітарного репертуару 3 метою популяризації творчості сучасних українських композиторів. Наукова новизна: дана праця є першою спробою детального аналізу «Іспанського концерту» для гітари із симфонічним оркестром М. Стецюна в українській гітаристиці. Висновки. Відтак, можна впевнено стверджувати, що остання чверть ХХ століття стала новітнім періодом розвитку національного гітарного мистецтва, а „Іспанський концерт” Миколи Стецюна $є$ одним 3 яскравих зразків сучасного українського концерту для гітари з оркестром, в якому пошук альтернативних канонічних рішень стає найоптимальнішим засобом вияву індивідуальної позиції митця, полем художнього експерименту. Стилістика твору поєднує риси двох національних шкіл, що дає можливість розкрити риси єдності музичних культур на різних рівнях: драматургічному, композиційному, інтонаційному. Авторське бачення національної характерності образної сфери цього твору реалізується через сучасну музичну мову. Композитору вдалось використати виразові і технічні можливості гітари, прийоми регістрово-тембрової контрастності, кантиленну природу інструмента.

Ключові слова: «Іспанський концерт» М. Стецюна, Концерт для гітари 3 симфонічним оркестром, Гітарне мистецтво, Національний репертуар, Творчий метод композитора, Гітара в Україні, Інструментальне виконавство.
\end{abstract}

Тущенко Михаил Михайлович, старший преподаватель института искусств Киевского университета имени Бориса Гринченко

Н. Стецюн „Испанский концерт” для гитары с оркестром: к вопросу создания национального репертуара в области гитарного искусства

Цель работы - детальный анализ «Испанского концерта» для гитары с симфоническим оркестром Н. Стецюна, раскрытие его интонационного и композиционного единства, особенностей творческого метода композитора. Особое внимание исследователь уделяет стилистике произведения для проявления сочетание черт двух национальных школ - украинской и испанской (фламенко). Методом исследования был выбран стилистический, композиционный и интонационный анализ произведения. Актуальность работы заключается в ее соответствии современным потребностям национального искусства и образования, а именно в появлении исследований новейшего гитарного репертуара с целью популяризации творчества современных украинских композиторов. Научная новизна: данная работа является первой попыткой детального анализа «Испанского концерта» для гитары с симфоническим оркестром Н. Стецюна в украинской гитаристике. Выводы. Следовательно, можно уверенно утверждать, что последняя четверть XX века стала новейшим периодом 